\title{
GEOARCHAEOLOGICAL STUDIES IN URBAN AND SUBURBAN AREAS OF THE ARGOLIS PREFECTURE.
}

\author{
Zananiri I. ${ }^{1}$, Chiotis E. ${ }^{1}$, Tsombos P. ${ }^{1}$, Hademenos V. ${ }^{1}$ and Zervakou A. ${ }^{1}$ \\ ${ }^{1}$ Institute of Geology and Mineral Exploration (I.G.M.E.), Division of General Geology and Geological \\ Mapping,1 Spirou Loui str., Olympic Village,3rd Entrance, 13677 Acharnae, Greece, izanan@igme.gr, \\ echiotis@otenet.gr,ptsombos@igme.gr,bashadem@hotmail.com,zervakou@igme.gr
}

\begin{abstract}
The application of earth science principles and techniques to the understanding of the archaeo-logical record has become a common practice, while reducing the archaeological risk is possible by clarifying areas of archaeological potential at an early stage. Towards this scope non-invasive geophysical magnetometry surveys were carried out at the city of Argos, successfully locating areas of interest for future excavations. Geoarchaeology studies in the Argolis Prefecture also involved the spatial location of the archaeological protection zones in the city of Nafplio, by combining data from the Official Government Gazettes, aerial photographs and high-resolution satellite images. Another study dealt with the palaeogeographic evolution of the broader Palea Epidavros area; fieldwork comprised electric resistivity soundings, total field magnetic measurements and two research boreholes at different altitudes. Finally, geoarchaeological research was employed to locate rocks suitable for the restoration of the Grave Circle A of Mycenae. The data management and cartographic representation was performed, in all cases, using Geographic Information Systems, where a geographic database was created, including all available information: local geology, topographic features, satellite images and archaeological data.
\end{abstract}

Key words: geoarchaeology, magnetometry, electric resistivity, GIS, Argolis prefecture.

\section{Introduction}

Geoarchaeology is an approach to the study of archaeological issues using the methods and concepts of the earth sciences. Attention is focused on the physical context of archaeological remains, especially in relation to geomorphological processes, site formation, post-depositional transformations, and the relationships between cultural and natural processes [Geoarchaeology (n.d.), 2010]. Modern geoarchaeological research makes use of a vast number of sophisticated techniques that either have been used in geology and pedology or have been developed or refined for geoarchaeological purposes.

Towards this scope, advanced geophysical techniques have been widely employed over the past decades to assist archaeologists during excavation planning (e.g. Patella and Hesse, 1999; Sarris and Jones, 2000; Gaffney and Gater 2003, Vafidis et al., 2005; English Heritage, 2008). Their application is based on the detection of inhomogeneities of the geophysical parameters of the ground, caused by the presence of buried archaeological structures and artefacts. Detailed magnetometry is a rapid, effective and non-invasive tool for the localization of buried structures (e.g. Tsokas et al., 1986, 1994) and constitutes the basis of archaeological surveying, complemented where necessary 


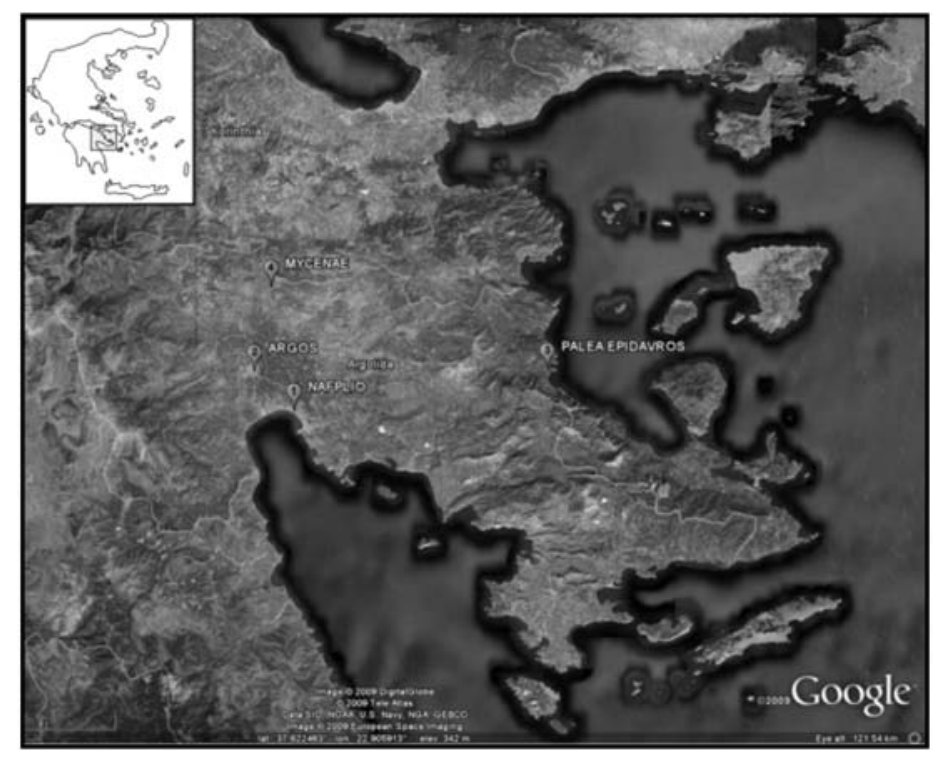

Fig. 1: Satellite image - taken from Google Earth - showing the location of the studied sites in the Argolis prefecture.

by ground penetrating radar, electric and electromagnetic methods (e.g. Sambuelli et al., 1999; Kvamme, 2001; Diamanti et al., 2005; Drahor, 2006; Papadopoulos et al., 2009).

The Institute of Geology and Mineral Exploration (I.G.M.E.) of Greece, in the frame of "Community Support Framework 2000 - 2006", Operational Program "Competitiveness", implemented the project called "Collection, codification and documentation of geothematic information for urban and suburban areas in Greece. Pilot studies". In the framework of subproject 3 "Integrated geological, geotechnical, hydrogeological, geochemical, geophysical and marine studies of the urban and suburban pilot area of Nafplio, Argolis municipality", geoarchaeological investigations were carried out in urban archaeological locations. This paper presents the preliminary results from the application of archaeological geophysics at the city of Argos and the town of Palea Epidavros, as well as data from two geoarchaeology studies that involve the city of Nafplio and the $1^{\text {st }}$ Grave Circle in the acropolis of Mycenae (Fig. 1).

\section{Geological setting}

The Argolis Peninsula consists of a stack of tectonic units, comprising ophiolites as well as deep water and platform sediments deposited at the Pelagonian margin (Pomoni-Papaioannou and Photiades, 2007). It comprises a composite nappe pile (Bortolotti et al., 2003 and references therein) of several imbricated pre-Neogene tectonic units, tectonically assembled in two major distinct tectonic phases, one in the late Jurassic and the other in the late Eocene (Photiades and Skourtsis-Coroneou, 1994). The study area is covered by three adjacent geological map sheets of 1:50.000 scale, namely the Argos (Papastamatiou et al., 1970), Ligourion (Tataris et al., 1970) and Nafplion (Bannert et al., 1984), the latter two recently updated by Photiades (pers. communication). A detailed analysis of the local geology can be found in Photiades $(2008,2010)$. 

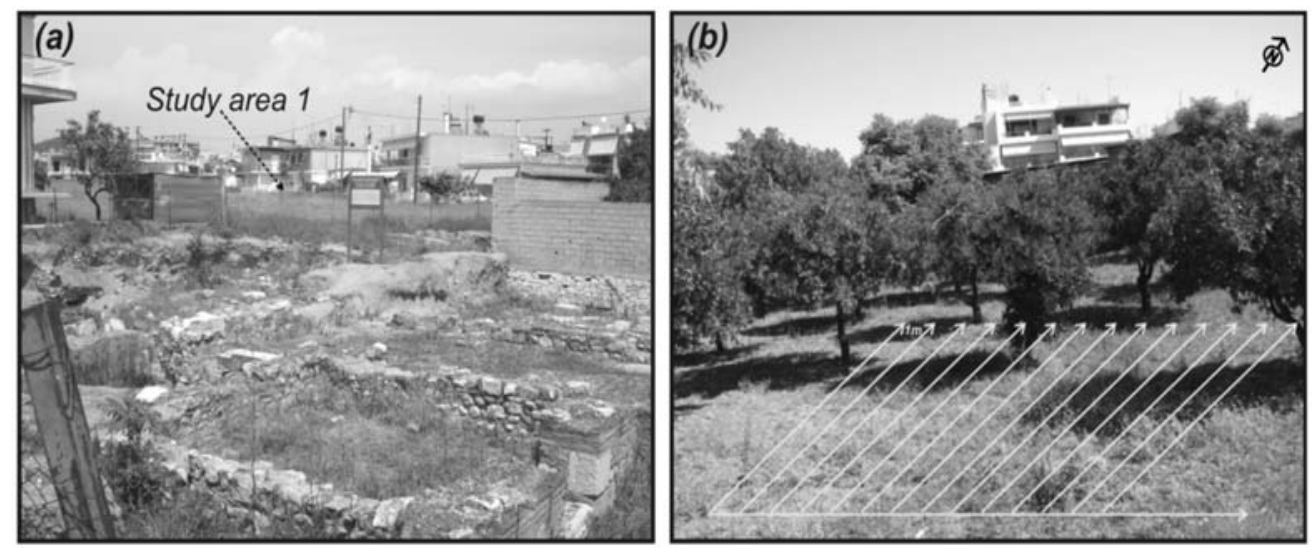

Fig. 2: (a) Remains of occupation structures revealed during excavation by the $4^{\text {th }}$ Ephoria of Prehistoric and Classical Antiquities (E.P.C.A.) nearby the study area. The remnants were buried at about $0.5 \mathrm{~m}$ depth. Site 1 of the present study is seen in the background; (b) General view of site 2, where the layout of the measuring grid is shown.

\section{Argos}

The city of Argos, today an agricultural and industrial centre of the Argolis Prefecture, was one of the most prominent city-states from the beginning of Archaic Times (c. 800 B.C.) and through to Classical Times. The modern city is mainly built on a $1.5-5.0 \mathrm{~m}$ elevated surface of alluvial deposits (Pitéros, 1998), that overlay ancient habitation ruins.

In order to reduce risk in archaeological excavations by identifying areas of high potential at an early stage a non-invasive geophysical survey was carried (Zananiri and Zervakou, 2008; Zananiri, 2009, Zananiri et al. 2010). Based on historical and archaeological evidence three sites were chosen near the ancient Agora of Argos (Fig. 2) and at the outskirts of the city. Total field and gradient magnetic measurements were collected over several grids, with $1 \mathrm{~m}$ spacing between measurement points. Representative samples from the top-soil and possible construction materials were taken for laboratory measurements of the low-field magnetic susceptibility, enabling a qualitative estimation of the nature of the expected magnetic anomalies. For example, positive magnetic anomalies may represent the remains of brick walls, while negative anomalies can correspond to limestone constructions in a relatively high susceptibility environment. Mapping, filtering and inversion procedures of the magnetic data have been used in tandem (Fig. 3). The data management and cartographic representation was performed using Geographic Information Systems, where a geographic database was created, including all available information for the broader Argos area. The results of the geophysical survey were able to highlight the presence of linear and geometric structures possibly representing inhabitance ruins, namely small building remnants and road foundations according to observations from neighbouring excavations. As can be seen in Figure 4 the general anomaly directions of a $20 \times 20$ grid, located near the ancient Agora of Argos are trending NW-SE parallel to the suggested positions of the main ancient roads at the city of Argos (Pausanias II, 19.3). Thus, the authors were able to suggest to the archaeologists excavation tests on the basis of the residual magnetic map.

\section{Nafplio}

Geoarchaeology studies in the Argolis Prefecture also involved the spatial location of the archaeo- 

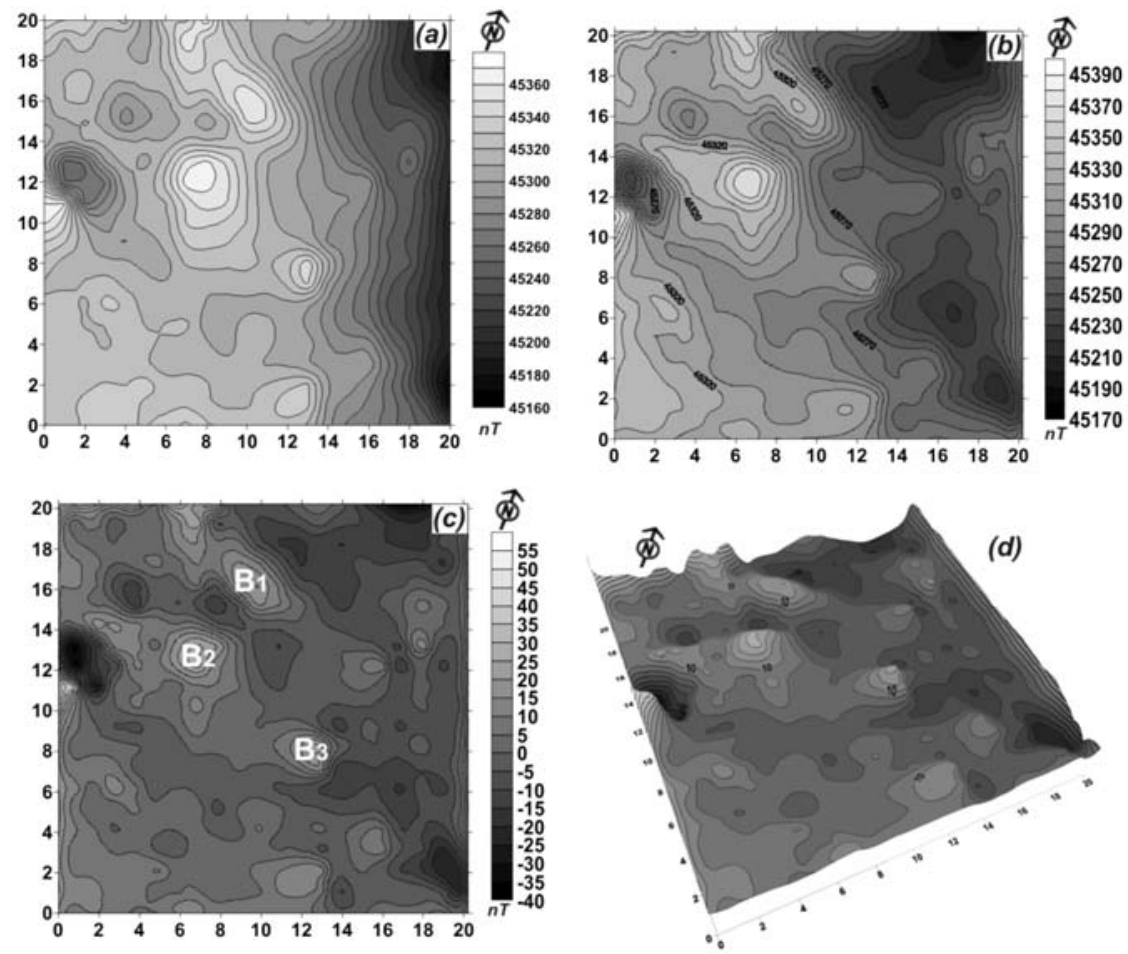

Fig. 3: Magnetic survey results from a $20 \times 20$ grid, located near the ancient Agora of Argos: (a) Raw data of the total magnetic field (after diurnal correction and despiking); (b) reduction to pole; (c) residual field and (d) 3 -D mapping of the residual magnetic field. The letters $\mathrm{B}_{1}, \mathrm{~B}_{2}$ and $\mathrm{B}_{3}$ denote areas having high positive anomalies, which may correspond to foundation remnants, e.g. pillars from the corners of buildings.

logical protection zones in the city of Nafplio. These zones were defined by the Hellenic State and published in the Official Government Gazettes, however their location was not easily accessible to the general public and a need for an intelligible visual representation was imminent. This task was carried out by combining data from the Official Government Gazettes, aerial photographs and highresolution satellite images in a GIS environment. Thus, a detailed mapping of the limits of zone A - totally protected, no construction allowed - and zone B - partially protected, conditional construction allowed - was performed (Fig. 4).

In this way that information is easily accessible by the local authorities, the scientific community and the general public, providing a handy tool for monitoring the current situation and effectively planning urban development of the city of Nafplio.

\section{Palea Epidavros}

The ancient town of Palea Epidavros, inhabited since the $3^{\text {rd }}$ millennium B.C., has not been systematically excavated; however, numerous ruins, from different eras, outcrop all over the so-called "Nisi", which is the Greek term for island, peninsula. The ancient theatre, t.i. the Small Theater of Ancient Epidavros, is found on the western side of the peninsula, near the slope of the strait connecting the Nisi peninsula with the mainland. Noteworthy is the fact that Pausanias, when during his travels visited the area in the middle of $2^{\text {nd }}$ century A.D. refers to the temples, the agora and the sea- 


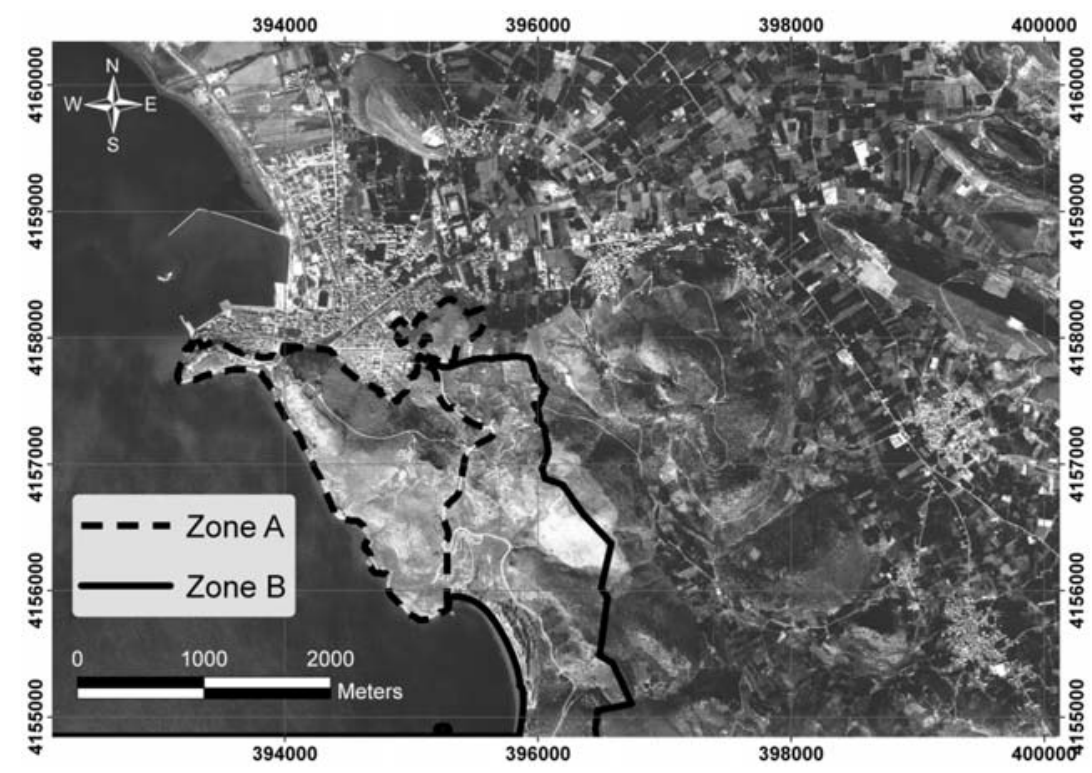

Fig. 4: Orthophoto mosaic from the broader Nafplio area, where the archaeological protection zones for the city of Nafplio are shown.

port, but does not mention the theatre. Thus, several questions arise concerning the palaeogeographic evolution of the area and especially the strait of Nisi.

Towards this scope a geophysical and stratigraphy study was carried out (Zananiri, 2009) in the broader area of Palea Epidavros, in order to investigate the possible presence of a marine channel between the Nisi peninsula and the main coast. The fieldwork comprised 17 vertical electric soundings (Figs. $5 \& 6$ ) and measurements of the total magnetic field at a total of 90 stations; finally in May 2008 two exploratory boreholes were drilled, reaching $12.16 \mathrm{~m}$ and $14.40 \mathrm{~m}$ respectively. The locations of the fieldwork activities were determined in collaboration with archaeologists from the $4^{\text {th }}$ Ephoria of Prehistoric and Classical Antiquities (E.P.C.A.). A preliminary examination of the drilled cores has been carried out, while detailed textural examination is in progress. Finally, laboratory magnetic measurements (Fig. 7) were performed on samples from both cores, taken every 10-15cm: low and high field magnetic susceptibility, frequency dependence calculation, isothermal remanence acquisition and thermomagnetic analyses. The data management and cartographic representation was performed using Geographic Information Systems and Google Earth platform.

\section{Grave Circle A of Mycenae}

The Grave Circle A of Mycenae (Fig. 8), excavated in the 1876 by Schliemann, is among the most important prehistoric monuments of Greece, very well known for the rich findings and the gold masks of the royal burials dated to the $16^{\text {th }}$ century B.C. Later, in the $13^{\text {th }}$ century B.C., the graves were enclosed by upright slabs of stone, forming two concentric circles.

The target of the survey (Chiotis et al., 2006), assigned to I.G.M.E. by the Committee for the restoration of Mycenae, was to localize similar rocks, proper for the restoration of these concentric circles.

The slabs of the monument consist by $84 \%$ of bioclastic limestone; they are frequently rich in siz- 


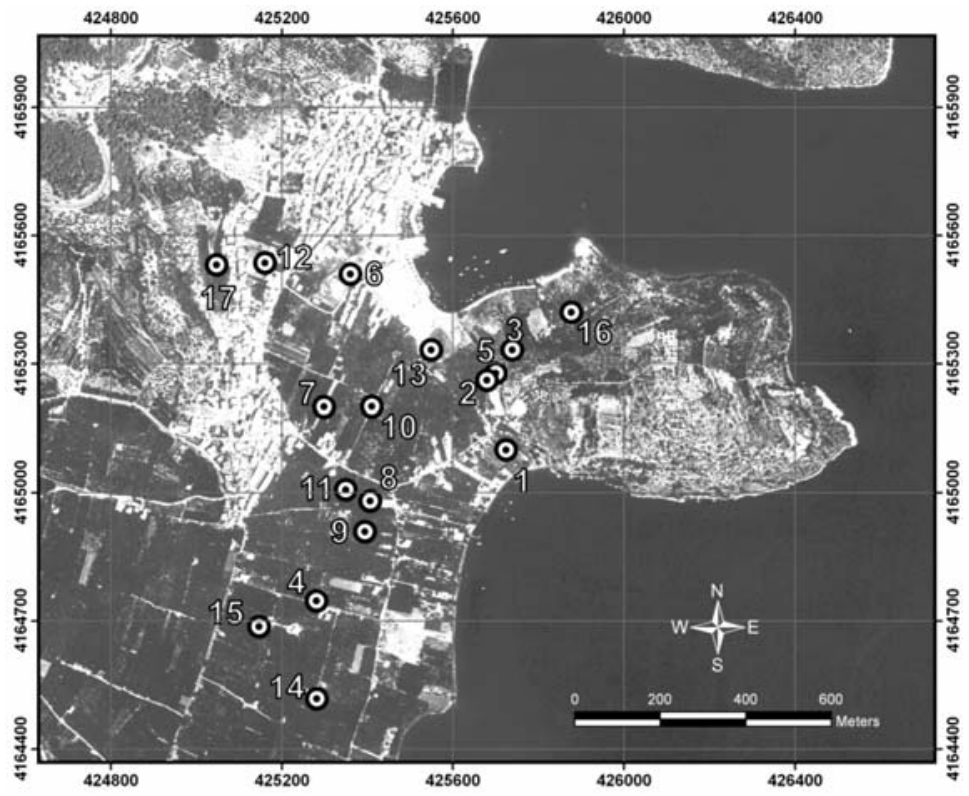

Fig. 5: Satellite image of the broader Palea Epidavros area where the location of the VESs is shown.
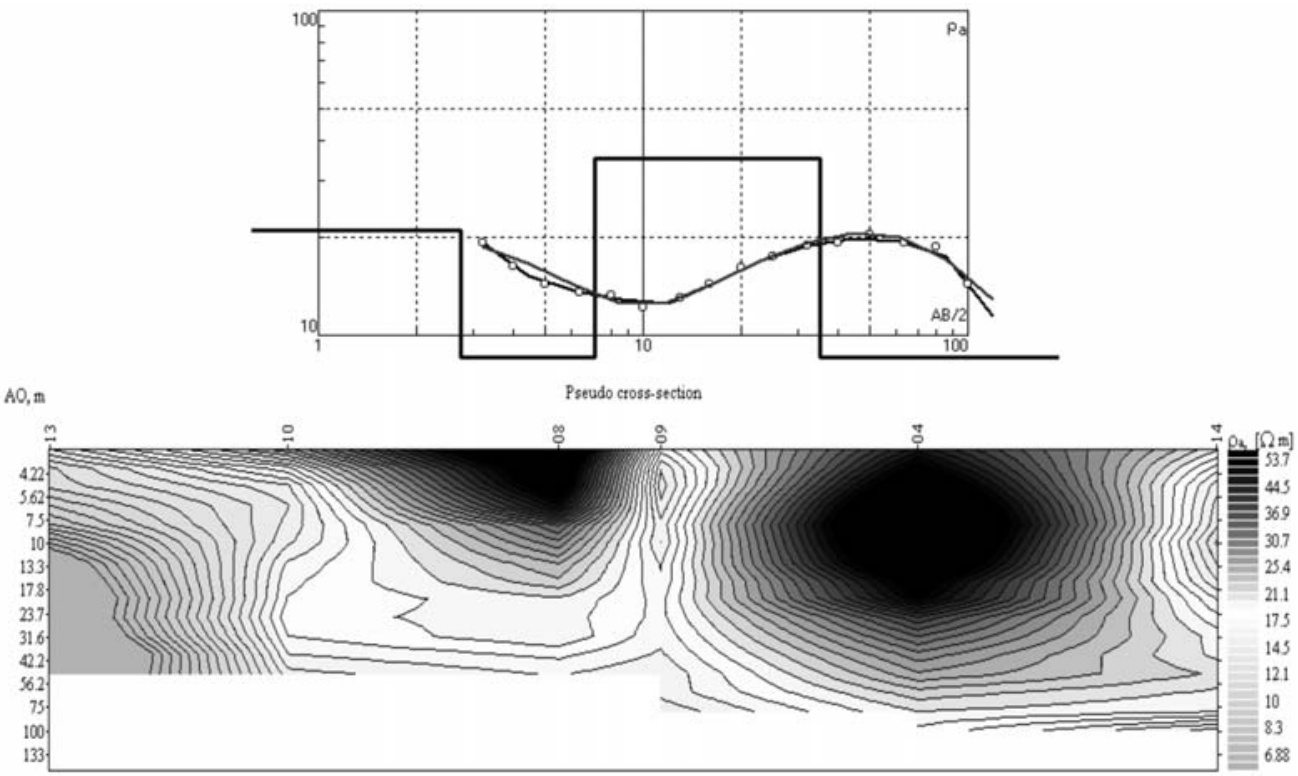

Fig. 6: An example of a vertical electric sounding (top) and the corresponding pseudo cross-section of apparent resistivity (bottom). 

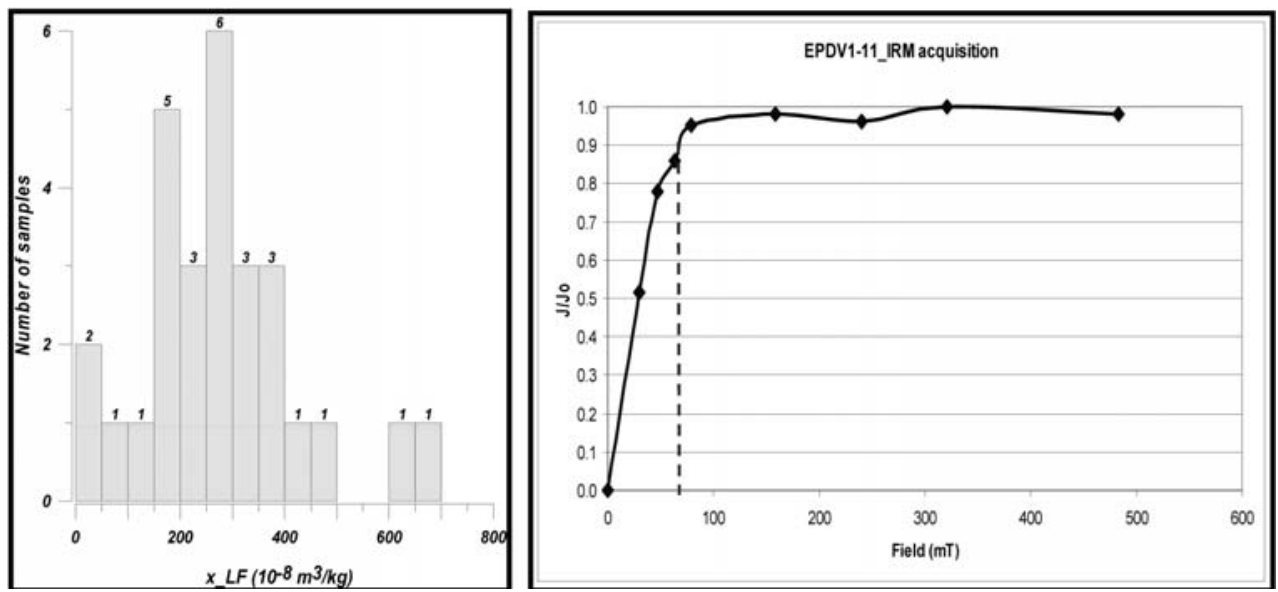

Fig. 7: Low field magnetic susceptibility histogram (left) and isothermal remanent magnetization acquisition curves (right) from samples extracted from the Epidavros boreholes.
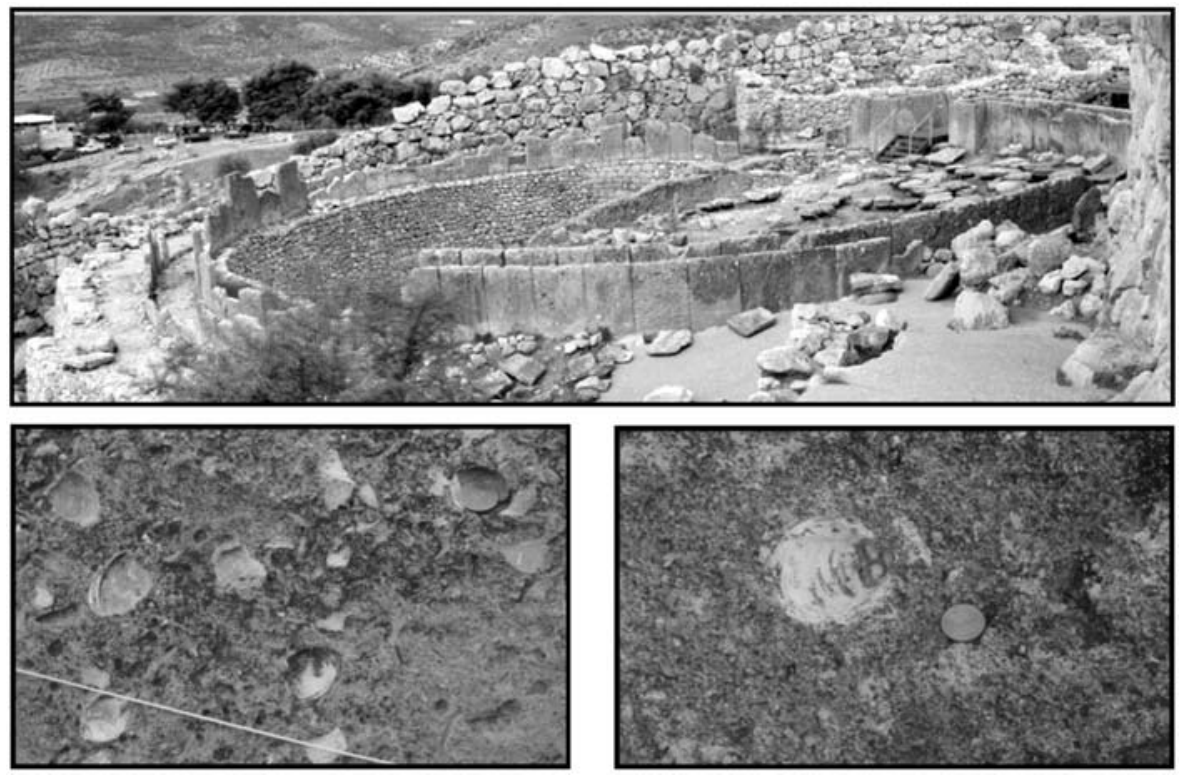

Fig. 8: Grave Circle A of Mycenae: view from SE (top) and typical images of fossiliferous rocks from the Grave Circle columns (bottom).

able fossils indicating a littoral marine environment of sedimentation. The rest participating rock types are sandstone, occasionally fossiliferous, fine conglomerate and oolithic limestone. Palaeontological and lithofacial criteria were suggestive of a Pleistocene age; taking into account the geological setting of the broader area, located near the Gulf of Corinth - an active extensional basin, the search for similar rocks was focused on the Tyrrhenian formations, starting from the outcrops in Nafplion and shifting successively to Corinth, Loutraki and Perachora areas (Zananiri et al., 2008 and references therein). The requirement of the restoration team for compact slabs, $(1 \times 1.5 \times 0.15 \mathrm{~m})$ 

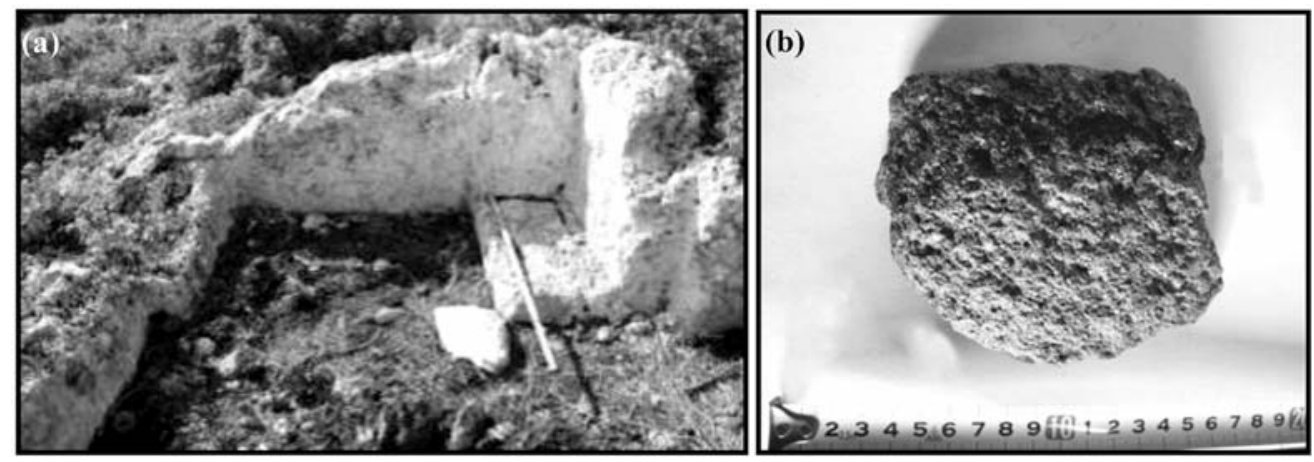

Fig. 9: (a) Ancient quarry of fossiliferous limestone in a Tyrrhenean marine terrace at Perachora peninsula; (b) Volcanic grinder.

large, was a serious restriction that excluded many of the already mapped geological outcrops. Proper formations with sufficient reserves were localized in the area of Perachora, near the Vouliagmeni Lake. The Tyrrhenian outcrops in Perachora occur in terraces which are tectonically uplifted up to an elevation of $160 \mathrm{~m}$. The prehistoric quarries (Fig. 9a) used for the excavation of the slabs of the Grave Circle A were also found in Perachora, very close to Mycenaean chamber tombs. The excavated blocks were surrounded by trenches, $12 \mathrm{~cm}$ wide, partly opened by rock abrasion through the use of volcanic rocks (Fig. 9b). A similar grinder of volcanic rock was also found in the monument, apparently used for smoothing the slabs.

\section{Conclusions}

The discipline of geoarchaeology, where geology sides with archaeology towards the study and preservation of our cultural heritage, is highly prominent worldwide and during the past few decades is being developed in Greece as well. The Institute of Geology \& Mineral Exploration, in the framework of C.S.F. 2000 - 2006 implemented geoarchaeological research in the broader area of Argolis Prefecture, one of the most active regions in Greece in terms of archaeological excavations that have taken place during the past decades. The studies presented here constitute a joint initiative by the I.G.M.E. and the archaeologists of the $4^{\text {th }}$ Ephoria of Prehistorical and Classical Antiquities towards the development of a systematic geoarchaeological survey in the Argolis Prefecture.

From the realization of these projects, and a preliminary interpretation of the results, several conclusions were drawn and important information was provided:

- The magnetic survey, at the city of Argos, provided indications for the location and burial depth of occupational remnants.

- A detailed mapping of the archaeological protection zones around the city of Nafplio was accomplished.

- There are indications that a marine channel used to separate the Nisi peninsula from the main land at Palea Epidavros

- Ancient quarries of fossiliferous limestones, suitable for the restoration of the Grave Circle A columns, were found in Tyrrhenean marine terraces at Perachora peninsula.

However, it is important to point out that geophysical surveys and other applied geological techniques do not substitute archaeological excavations but can contribute significantly to an optimum excavation planning by defining areas of increased interest and thus cut down excavation cost and time. 


\section{Acknowledgements}

This work was funded by the Community Support Framework 2000 - 2006 (Operational Program "Competitiveness"). We would like to thank A. Banaka, Director of the $4^{\text {th }}$ Ephoria of Prehistoric and Classical Antiquities at Nafplio, and Ch. Pitero, Assistant Director, for their support and encouragement in the application of earth sciences towards the rescue of cultural heritage. G. Papathanasopoulos, Ch. Antoniadis, E. Paleologou, G. Biniaris, S. Spiropoulou and G. Tzavalis are greatfully acknowledged for providing invaluable information and assistance during the conception and realization of this project. We thank all colleagues who participated in this multidisciplinary research and especially Dr. A. Photiadis, Dr. E. Dimou, G. Efthimiou, and D. Mitropoulos. P. Tsailas kindly provided geomagnetic data from the Magnetic Observatory of I.G.M.E. Prof. D. Kondopoulou is warmly thanked for allowing the use of the facilities at the Palaeomagnetic Laboratory of the Aristotle University of Thessaloniki. Finally, we are especially grateful to Prof. A. Georgakopoulos, former General Director of I.G.M.E., for his encouragement and support towards the development of geoarchaeological research.

\section{References}

Bannert, D., Kalkreuth, W. and Wallner, 1984. Geological map scale 1:50.000. Sheet of Nafplion. Institute of Geology and Mineral Exploration, Athens, Greece.

Bortolotti, V., Carras, N., Chiari, M., Fazzuoli, M., Marcucci, M., Photiades, A. and Principi, G., 2003. The Argolis Peninsula in the palaeogeographic and geodynamic frame of the Hellenides. Ofioliti, 28/2, 79-94.

Chiotis, E., Tsombos, P. and Photiades, A., 2006. Report of the results from a geological survey for the recommendation of proper rocks for the restoration of the Grave Circle A in Mycenae. Institute of Geology \& Mineral Exploration, Athens, pp.31.

Diamanti, N.G., Tsokas, G.N., Tsourlos, P.I. and Vafidis, A., 2005. Integrated interpretation of geophysical data in the archaeological site of Europos (Northern Greece). Archaeological Prospection 12, 79-91.

Drahor, M.G., 2006. Integrated geophysical studies in the upper part of Sardis archaeological site, Turkey. Journal of Applied Geophysics 59, 205-223.

English Heritage, 2008. Geophysical Survey in Archaeological Field Evaluation. English Heritage, Swindon, pp. 60.

Gaffney, C. and Gater, J., 2003. Revealing the buried past: geophysics for archaeologists. Stroud, Tempus.

Geoarchaeology (n.d.), 2010. The Concise Oxford Dictionary of Archaeology. Retrieved January 21, 2010, from Answers.com Web site: http://www.answers.com/topic/geoarchaeology-1

Kvamme, K.L., 2001. Current practices in archaeogeophysics. In: Earth Sciences and Archaeology (Eds. Goldberg, P., Holliday, V.T. \& Ferring, C.R.), Kluwer Academic/Plenum New York, pp.353-384.

Papadopoulos, N., Sarris, A., Yi, M.J. and Kim, J.H., 2009. Urban archaeological investigations using surface 3D Ground Penetrating Radar and Electrical Resistivity Tomography methods. Exploration Geophysics 40(1), 56-68.

Patella, D. and Hesse, D.A., 1999. Electric, Magnetic and Electromagnetic methods applied to cultural heritage. Journal of Applied Geophysics, Special Issue 41, 135-311.

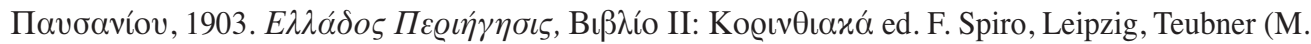
l'abbé Gedoyn, 1731, Pausanias: Voyage historique de la Grèce / traduit en François. Tome douzième chez Didot Paris). 
Papastamatiou, I., Vetoulis, D., Tataris, A., Christodoulou, G., Bornovas, I., Lalechos, N. and Kounis, G., 1970. Geological map scale 1:50.000. Sheet of Argos. Institute of Geology and Mineral Exploration, Athens Greece.

Photiades, A. and Skourtsis-Coroneou, V., 1994. Stratigraphic and paleogeographic evolution of the Northern Argolis (Greece) during the Cretaceous - Paleogene. Bull. Geol. Soc. Greece, vol. XXX/2, 135146.

Photiadis A., 2008. Geological study of the urban and the wider Nafplio area. Argolida Prefecture. Institute of Geology and Mineral Exploration, Athens.

Photiadis A., 2010. Geological survey in scale 1:5.000 of the greater Nafplion area (NW Argolis, Greece). Bulletin of the Geological Society of Greece, Proceedings of the $12^{\text {th }}$ International Congress (this volume).

Pitéros, Ch., 1998. Contribution a la topographie Argienne. Le site, les remparts et quelques problèmes topographiques. Recherches Franco-Helléniques III, 179-210.

Pomoni-Papaioannou, F. and Photiades, A., 2007. Stacked loferite cycles and paleosoils (Upper Triassic, Argolis Peninsula, Greece), Proc. 25 th IAS Meeting, Patras, Greece, p. 141.

Renfrew, C., 1976. Archaeology and the earth sciences. In: Geoarchaeology: Earth Science and the Past (Eds D.A. Davidson \& M.L. Shackley), Duckworth, London, pp. 1-5.

Sambuelli, L., Socco, L.V. and Brecciaroli, L., 1999. Acquisition and processing of electric, magnetic and GPR data on a Roman site (Victimulae, Salussola, Biella). Journal of Applied Geophysics 41, 189204.

Sarris, A. and Jones, R., 2000. Geophysical and related techniques applied to archaeological survey in the Mediterranean: A Review. Journal of Mediterranean Archaeology, 13(1), 3-75.

Tataris, A., Kallergis, G. and Kounis, G., 1970. Geological map scale 1:50.000. Sheet of Ligourion. Institute of Geology and Mineral Exploration, Athens, Greece.

Tsokas, G.N., Rocca, A.Ch. and Papazachos, B.C., 1986. Magnetic prospecting at the Prehistoric site of the village Mandalo in Northern Greece. P.A.C.T. 15, 143-152.

Tsokas, G.N., Giannopoulos, A., Tsourlos, P., Vargemezis, G., Tealby, J.M., Sarris, A., Papazachos, C.B. and Savopoulou, T., 1994. A large scale geophysical survey in the archaeological site of Europos (northern Greece). Journal of Applied Geophysics 32, 85-98.

Vafidis, A., Economou, N., Ganiatsos, Y., Manakou, M., Poulioudis, G., Sourlas, G., Vrontaki, E., Sarris, A., Guy, M. and Kalpaxis, Th., 2005. Integrated geophysical studies at ancient Itanos (Greece). Journal of Archaeological Science 32, 1023-1036.

Zananiri, I. and Zervakou, A., 2008. Geoarchaeological survey at the broader Argos area, Argolis Prefecture. Institute of Geology \& Mineral Exploration, Athens, pp. 32.

Zananiri, I., Tsombos, P., Photiades, A. and Chiotis, E., 2008. The Gulf of Corinth as an international geological laboratory. The case of Perachora peninsula. Bull. Geol. Soc. Greece, Proceedings of the Conference "Land and Sea of Korinthos", XXXVI, 53-64.

Zananiri, I., 2009. Geomagnetic survey at the city of Argos, Argolis Prefecture. Institute of Geology \& Mineral Exploration, Athens, pp. 26.

Zananiri, I., Hademenos, V. and Piteros, Ch., 2010. Geophysical investigations near the ancient Agora at the city of Argos, Greece. Journal of Geophysics and Engineering, Vol. 7. 